\title{
EFFECTS OF ORGANICAL AND CONVENTIONAL GROWING ON THE CONTENT OF BIOLOGICALLY ACTIVE COMPOUNDS OF POTATOES
}

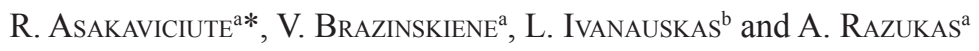 \\ ${ }^{\mathrm{a}}$ Voke branch of Lithuanian Research Centre for Agriculture and Forestry, Zalioji a. 2, Traku Voke, LT-02232 \\ Vilnius. Lithuania \\ ${ }^{b}$ Department of Analytical and Toxicological Chemistry, Lithuanian University of Health Sciences, \\ A. Mickeviciaus g. 9, LT-44307, Kaunas. Lithuania
}

(Received: 30 August 2016; accepted: 12 December 2016)

\begin{abstract}
It was determined that amounts of chlorogenic acid, tyrosine, and tryptophan in potato tubers depend on meteorological conditions, farming type, individual properties of a variety, and interaction of these factors $(\mathrm{P}<0.05)$. It was noted in 2011 that organically grown potato tubers accumulated significantly higher amounts of chlorogenic acid, tyrosine, and tryptophan derivatives than conventionally grown tubers, while in 2012 the opposite was observed $(\mathrm{P}<0.01)$. Such results are due to the different meteorological conditions during the survey years.

Keywords: Solanum tuberosum, conventional and organic farming, chlorogenic acid, tyrosine, tryptophan
\end{abstract}

Potatoes are able to easily adapt to different growing conditions, produce high yields, are of high nutritional value, so they are very widespread and considered as the most important nongrain agricultural plant in the world. According to the data of the United Nations Food and Agriculture Organization (FAO), potatoes are the fourth most consumed food crop in the world after rice, wheat, and corn (FAO, 2011).

Potatoes raise interest not only as nutritive crop, their health improving properties are also being studied widely. Potato tubers are beneficial for human health as they accumulate vitamins, minerals, and significant quantities of phenolic compounds. After investigations on the contribution of phenolic compounds of 34 fruit and vegetables in the American diet, CHUN and co-workers (2005) revealed that potatoes are the third source of phenolic compounds in daily diet after apples and oranges.

Recently, both in Lithuania and around the world a lot of attention is given to food safety and quality. The popularity of organic food may be attributable to the perception that organic food is healthier, safer, and tastier than conventionally produced food (HAJSLOva et al., 2005; GiLSENAn et al., 2010). In order to prove it, contents of various compounds (pesticides, nitrates, minerals, vitamins, phenolic compounds, and other substances) accumulated in organically and conventionally grown food are often compared (DANGOUR et al., 2009).

Currently there is no unanimous opinion about the impact of farming type on the antioxidant activity of potato tubers and the amounts of accumulated phenolic compounds, but it is known that accumulation of phenylpropanoids in potato tubers is stimulated by various abiotic and biotic factors (TÖMÖSKÖZI-FARKAS et al., 2014a; PinEROs-Nino et al., 2016). It is likely that organically grown potato tubers would accumulate higher amounts of

\footnotetext{
* To whom correspondence should be addressed.

Phone: +370 5 2645439; fax: +370 5 2645430; e-mail: rita.asakaviciute@voke.lzi.lt
} 
phenylpropanoids (chlorogenic, caffeic, and other acids) with antioxidant activity, because without the use of chemical protection measures, the tubers would be more strongly influenced by such factors as pests and diseases, which stimulate the synthesis of these compounds.

In literature review on the assessment of the effect of farming type on vegetables, HOEFKENS and co-workers (2008) stated that from the nutritional and toxicological points of view organic vegetables are not significantly better than the conventional. In terms of specific substances found in vegetables, in certain cases organic vegetables are much better, while in other cases the opposite was found (TömösкöZI-FARKas et al., 2014b; Meena et al., 2016). The lack of comprehensive twinning (organic and conventional) analyses of farming types limits the correct evaluation of their effects on vegetable quality.

The former phytochemical analysis studies show that potato accumulates a wide variety of biologically active compounds, and among the more important ones are two classes of phenolic compounds, phenolic acids (mainly chlorogenic acid) and aromatic amino acids (tyrosine, tryptophan). Our research objective was to investigate the effects of organic and conventional farming on accumulated chlorogenic acid, tyrosine, and tryptophan in potato tubers.

\section{Materials and method}

\subsection{Plant material}

Potato (Solanum tuberosum L.) tubers of several cultivars with different time of maturity: very early - 'VB Venta', 'Fresco', 'Acapella'; early - 'Sante', 'Goda', 'VB Liepa'; medium - 'Lady Rosetta', 'Red Lady', 'Courage', and late - 'Saturna', 'VB Rasa', 'VB Aista'.

\subsection{Meteorological conditions}

Meteorological conditions during the research period (the years 2011 and 2012) are described by the following data presented by Traku Voke (Lithuania) meteorological station and the calculated hydrothermal coefficients (HTC).

Meteorological conditions in Lithuania during 2011-2012 years varied (Table 1). May 2011 was more humid and slightly warmer compared to the multiannual average. May 2012 was drier and warmer, compared to both the multiannual average and 2011. June 2011 was much warmer (average temperature $2.6{ }^{\circ} \mathrm{C}$ above average multiannual), and precipitation was almost twice less than normal. The HTC value (1.0) shows insufficient humidity. June 2012 was marked by a temperature nearly a degree lower and precipitation higher by one third, compared to the multiannual average. The HTC value (2.0) shows the excess humidity. July during both years was approximately warmer by $2.5^{\circ} \mathrm{C}$ than the multiannual average. Precipitation was also high in both cases, but in 2011 it was almost twice the multiannual average. The HTC value (2.4) shows a great humidity excess. August 2011 was warmer and more humid, compared with 2012 and the multiannual average. In 2012, August was slightly warmer and wetter than the multiannual average.

\subsection{Organic and conventional farming conditions}

Potatoes were grown in 2011-2012 in Lithuania, Voke Branch of Lithuanian Research Centre for Agriculture and Forestry in breeding plots with sandy loam soil on carbonated fluvioglacial eluviated gravel (JDp), according to FAO UNESCO classification - Haplic Luvisol (LVh) 
(BuIVYDAITE, 2005), with the following agrochemical characteristics: $\mathrm{pH}_{\mathrm{KCl}}-5.9$, the content of absorbed bases $-105 \mathrm{mEq} \mathrm{kg}{ }^{-1}$ of soil, organic matter content $-2.1 \%$, available phosphorus $\left(\mathrm{P}_{2} \mathrm{O}_{5}\right)-230 \mathrm{mg} \mathrm{kg}^{-1}$ and available potassium $\left(\mathrm{K}_{2} \mathrm{O}\right)-310 \mathrm{mg} \mathrm{kg}^{-1}$.

Table 1. Meteorological data 2011-2012. Long-term average 1961-1990.

\begin{tabular}{|c|c|c|c|c|c|c|c|c|}
\hline \multirow{2}{*}{ Month } & \multicolumn{3}{|c|}{ Air temperature $\left({ }^{\circ} \mathrm{C}\right)$} & \multicolumn{3}{|c|}{ Precipitation (mm) } & \multicolumn{2}{|c|}{$\begin{array}{l}\text { Hydrothermal } \\
\text { coefficients }\end{array}$} \\
\hline & $\begin{array}{l}\text { Long-term } \\
\text { average }\end{array}$ & 2011 & 2012 & $\begin{array}{l}\text { Long-term } \\
\text { average }\end{array}$ & 2011 & 2012 & 2011 & 2012 \\
\hline May & 12.5 & 12.9 & 13.8 & 60 & 79 & 38 & 1.7 & 1.1 \\
\hline June & 15.7 & 18.3 & 14.8 & 77 & 41 & 99 & 1.0 & 2.0 \\
\hline July & 16.9 & 19.6 & 19.5 & 78 & 155 & 81 & 2.4 & 1.6 \\
\hline August & 16.3 & 17.3 & 16.5 & 68 & 101 & 93 & 1.8 & 1.1 \\
\hline
\end{tabular}

In the conventional farming type potatoes were grown in a breeding plot. The autumn field was sprayed with herbicide Kernel $480 \mathrm{SL} 31 \mathrm{ha}^{-1}$ (active substance glyphosate $480 \mathrm{~g}$ $1^{-1}$ ), then the soil was deeply ploughed. In spring, the field was cultivated twice, with a rotary cultivator to a depth of $0.25 \mathrm{~m}$. The field was furrowed before the potato planting; potatoes were planted by hand. Potatoes were fertilized with universal complex fertilizers (Kemira Cropcare $\mathrm{N}_{10} \mathrm{P}_{10} \mathrm{~K}_{20}$ ). At the time of planting, $80 \mathrm{~kg} \mathrm{ha}^{-1}$ of nitrogen, $80 \mathrm{~kg} \mathrm{ha}^{-1}$ of phosphorus, and $160 \mathrm{~kg} \mathrm{ha}^{-1}$ of potassium were added. After planting, the interrows were twice hilled up using a rotary hiller. When potatoes grew to $10 \mathrm{~cm}$, the field was sprayed with herbicide mixture (Titus $50 \mathrm{~g} \mathrm{ha}^{-1}$ (active substance rimsulfuron $250 \mathrm{~g} \mathrm{~kg}^{-1}$ ) with Mistral $500 \mathrm{~g} \mathrm{ha}^{-1}$ (active substance metribuzin $700 \mathrm{~g} \mathrm{~kg}^{-1}$ )). After that the potatoes were twice earthed up. At inflorescence formation and flowering period, plants were sprayed with fungicide Acrobat Plus $2 \mathrm{~kg} \mathrm{ha}^{-1}$ (active substances dimethomorph $90 \mathrm{~g} \mathrm{~kg}^{-1}$ and mancozeb $600 \mathrm{~g} \mathrm{~kg}^{-1}$ ) in combination with an insecticide Proteus OD $0.71 \mathrm{ha}^{-1}$ (active substances thiacloprid 100 $\mathrm{g} \mathrm{l}^{-1}$ and deltamethrin $10 \mathrm{~g} \mathrm{l}^{-1}$ ). After two weeks, fungicide Ridomil Gold $2.5 \mathrm{~kg} \mathrm{ha}^{-1}$ (active substances metalaxyl-M $40 \mathrm{~g} \mathrm{~kg}^{-1}$ and mancozeb $640 \mathrm{~g} \mathrm{~kg}^{-1}$ ) in combination with an insecticide Proteus OD $0.71 \mathrm{ha}^{-1}$ were used. Two weeks before harvest, the potato field was sprayed with fungicide Shirlan $500 \mathrm{SC} 0.41 \mathrm{ha}^{-1}$ (active substance fluazinam $500 \mathrm{~g} \mathrm{l}^{-1}$ ).

In the case of organic farming, potatoes were grown in a separate field. In autumn the soil was deeply ploughed. In spring, the field was cultivated twice, with a rotary cultivator to a depth of $0.25 \mathrm{~m}$. The field was furrowed before potato planting, potatoes were planted by hand. In the case of organic farming, at planting time $60 \mathrm{~kg} \mathrm{ha}^{-1}$ of nitrogen (Provita), $60 \mathrm{~kg}$ $\mathrm{ha}^{-1}$ of phosphorus (phosphorite powder), and $90 \mathrm{~kg} \mathrm{ha}^{-1}$ of potassium (Patentikali) were applied. Potatoes were earthed up and twice harrowed. After planting, the interrows were twice every week hilled up using a rotary hiller. In the organic farming potato field mechanical measures were used to fight weeds, the larvae of Colorado beetles were collected by hand and destroyed.

\subsection{Preparation of samples for analysis}

Five randomly chosen tubers were selected from the storage of each potato cultivar. Washed and air-dried potato tubers were cut into $4 \mathrm{~mm}$ thick slices with cutting machine TNS 200 
(Germany) and quickly frozen at $-35{ }^{\circ} \mathrm{C}$ in a freezer with air circulation. The frozen potato slices were lyophilized in Ilshin Freze Dryer FD8512S (ilShin ${ }^{\circledR}$ Europe, Ede, Netherlands) lyophyliser at 5 millitorr pressure (condenser temperature $-85^{\circ} \mathrm{C}$ ). Lyophilized potatoes were ground into powder (Grindomix GM 200, Retsch, Germany). When preparing an analytical sample, $1 \mathrm{~g}$ of the obtained power was placed into an analytical flask and poured over with a mixture of acetic acid, methanol, and water $(2: 39: 59 ; \mathrm{v} / \mathrm{v} / \mathrm{v})$ to $10 \mathrm{ml}$. The mixture then was placed into ultrasonic cleaner (Biosonic UC100, Coltene/Whaledent, USA) for 20 minutes. The obtained potato extract was filtered first through paper (Albet 400, Albetlab Sience, Germany) and then through syringe filter with nylon membrane with $0.22 \mu \mathrm{m}$ pore size (Rotilabo, Carl Roth GmbH, Germany). The extract prepared this way was analysed. Three extracts were prepared for each potato sample.

\subsection{HPLC analysis}

The analysis was carried out using Waters 2695 (Waters, Milford, USA) chromatograph. For separation of active compounds, $4.6 \times 250 \mathrm{~mm}, 5 \mu \mathrm{m}$ ACE C18 column (Advanced Chromatographic Technologies, Scotland) was used. During analysis it was kept at an external Waters temperature control module (Milford, USA) maintaining $25^{\circ} \mathrm{C}$ temperature. For the analysis, $10 \mu \mathrm{m}$ of test solution was injected. The mobile phase flow rate was $1 \mathrm{ml}$ $\mathrm{min}^{-1}$. The following gradient system was used: solvent $\mathrm{A}-0.5 \%$ acetic acid in water, solvent $\mathrm{B}-$ methanol; $0 \mathrm{~min}-95 \% \mathrm{~A}$ and $5 \% \mathrm{~B}, 40 \mathrm{~min}-40 \% \mathrm{~A}$ and $60 \% \mathrm{~B}, 41 \mathrm{~min}-10 \% \mathrm{~A}$ and $90 \% \mathrm{~B}, 55 \mathrm{~min}-10 \% \mathrm{~A}$ and $90 \% \mathrm{~B}, 56 \mathrm{~min}-95 \% \mathrm{~A}$ and $5 \% \mathrm{~B}$. The separated active compounds were analysed using photodiode array detector Waters 996PDA (Waters, Milford, USA) at a wavelength ensuring their maximum absorption: chlorogenic acid $-325 \mathrm{~nm}$, tyrosine -273 , and tryptophan $-277 \mathrm{~nm}$. Data were collected and analysed using Waters Millennium 2000 chromatographic manager system (Waters Corporation, Milford, USA).

\subsection{Statistical analysis}

The statistical assessment was carried out using analysis of variance (ANOVA). The analysis of variance was used to determine if significant differences existed among potato cultivars and farming systems. Differences were classified by LSD multiple comparison test $(\mathrm{P}<0.05)$.

\section{Results and discussion}

Chlorogenic acid account for up to $90 \%$ or more of the total content of phenolic compounds found in potato tubers. The amount of chlorogenic acid derivatives is determined by the interaction of meteorological conditions, farming type, and potato cultivar $(\mathrm{P}<0.001)$. The assessment of the amounts of these acids reveals that organically grown potatoes are more susceptible to changes in meteorological conditions (abiotic stress).

Due to significant interaction of the impact of the growth year and other factors, results of the years 2011 and 2012 are discussed separately. It was noted that in 2011 (Table 2) organically grown potato tubers accumulated significantly higher amount of chlorogenic acid derivatives, while in 2012 the opposite could be observed $(\mathrm{P}<0.001)$. Such results are due to different meteorological conditions during the survey years (2011 were less favourable for potato growth than 2012). 
ASAKAVICIUTE et al.: BIOACTIVE COMPOUNDS IN ORGANIC AND CONVENTIONAL POTATO 227

Table 2. Average amount of chlorogenic acid derivatives accumulated in organically and conventionally grown potato tubers of different cultivars

\begin{tabular}{|c|c|c|c|c|c|c|c|c|c|c|c|c|}
\hline \multirow[b]{2}{*}{ Years } & \multicolumn{12}{|c|}{ Amount of free hydroxycinnamic acid $\left(\mu \mathrm{g} \mathrm{g}^{-1)}\right.$} \\
\hline & $\begin{array}{c}\text { VB } \\
\text { Venta }\end{array}$ & $\begin{array}{l}\text { Aca- } \\
\text { pella }\end{array}$ & Fresco & $\begin{array}{c}\text { VB } \\
\text { Liepa }\end{array}$ & Sante & Goda & $\begin{array}{c}\text { Cour- } \\
\text { age }\end{array}$ & $\begin{array}{l}\text { Red } \\
\text { Lady }\end{array}$ & $\begin{array}{c}\text { Lady } \\
\text { Ro- } \\
\text { setta }\end{array}$ & $\begin{array}{l}\text { Sat- } \\
\text { urna }\end{array}$ & $\begin{array}{c}\text { VB } \\
\text { Rasa }\end{array}$ & $\begin{array}{c}\text { VB } \\
\text { Aista }\end{array}$ \\
\hline
\end{tabular}

Organically grown

$\begin{array}{lcccccccccccc}2011^{*} & 106 & 131 & 63 & 95 & 48 & 112 & 93 & 86 & 81 & 129 & 143 & 135 \\ 2012^{* *} & 65 & 86 & 60 & 49 & 62 & 62 & 80 & 56 & 59 & 85 & 96 & 53\end{array}$

Conventionally grown

$\begin{array}{lllllllllllll}2011^{*} & 126 & 94 & 58 & 66 & 42 & 57 & 89 & 79 & 75 & 108 & 128 & 66\end{array}$

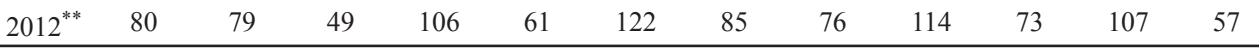

*: $\mathrm{LSD}_{0.05 \text { farming system }=} 4.99 ; \mathrm{LSD}_{0.05 \text { variety }} 12.23 ; \mathrm{LSD}_{0.05 \text { farming system } \times \text { cultivar }=} 17.29 ;{ }^{* *}: \mathrm{LSD}_{0.05 \text { farming system }=} 4.30 ; \mathrm{LSD}_{0.05}$ cultivar $=10.54 ; \mathrm{LSD}_{0.05}$ farming system $\times$ cultivar $=14.90$

Time of maturity significantly effects the accumulation of chlorogenic acid derivatives in potato tubers $(\mathrm{P}<0.01)$. It was found that in late cultivars from organic farming tend to accumulate significantly more hydroxycinnamic acid derivatives than other cultivars. In conventionally grown potatoes such trend was detected only for the year 2011.

Tyrosine content in potato tubers is determined by the interaction of year, farming type, and cultivar $(\mathrm{P}<0.001)$. Therefore, the results of the years 2011 and 2012 are discussed separately. It was noted that in 2011 (Table 3 ) organically grown potato tubers accumulated significantly higher amounts of tyrosine, while in 2012 the opposite was observed $(\mathrm{P}<0.001)$. In 2011, organically grown tubers accumulated more tyrosine compared with $2012(\mathrm{P}<0.05)$, while in conventionally grown potato tubers the amount of free tyrosine in 2011-2012 did not significantly differ $(\mathrm{P}>0.05)$.

Table 3. Average amount of free tyrosine accumulated in organically and conventionally grown potato tubers of different cultivars

\begin{tabular}{|c|c|c|c|c|c|c|c|c|c|c|c|c|}
\hline \multirow[b]{2}{*}{ Years } & \multicolumn{12}{|c|}{ Amount of free tyrosine $\left(\mu \mathrm{g} \mathrm{g}^{-1}\right)$} \\
\hline & $\begin{array}{l}\text { VB } \\
\text { Venta }\end{array}$ & $\begin{array}{l}\text { Aca- } \\
\text { pella }\end{array}$ & Fresco & $\begin{array}{c}\text { VB } \\
\text { Liepa }\end{array}$ & Sante & Goda & $\begin{array}{c}\text { Cour- } \\
\text { age }\end{array}$ & $\begin{array}{c}\text { Red } \\
\text { Lady }\end{array}$ & $\begin{array}{c}\text { Lady } \\
\text { Ro- } \\
\text { setta }\end{array}$ & $\begin{array}{l}\text { Sat- } \\
\text { urna }\end{array}$ & $\begin{array}{c}\text { VB } \\
\text { Rasa }\end{array}$ & $\begin{array}{c}\text { VB } \\
\text { Aista }\end{array}$ \\
\hline
\end{tabular}

Organically grown

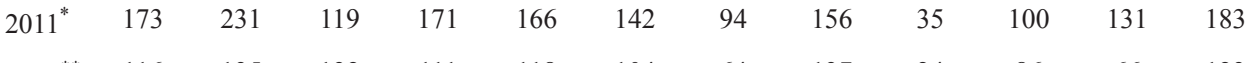

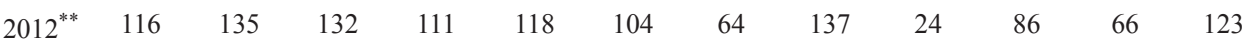

Conventionally grown

\begin{tabular}{lllllllllllll}
$2011^{*}$ & 191 & 182 & 147 & 99 & 132 & 68 & 135 & 175 & 27 & 80 & 96 & 112 \\
$2012^{* *}$ & 207 & 198 & 117 & 184 & 156 & 115 & 58 & 222 & 33 & 82 & 147 & 108 \\
\hline
\end{tabular}

*: $\mathrm{LSD}_{0.05 \text { farming system= }} 6.99 ; \mathrm{LSD}_{0.05 \text { cultivar= }} 17.13 ; \mathrm{LSD}_{0.05 \text { farming system } \times \text { cultivar }=} 24.22 ;{ }^{* *}: \mathrm{LSD}_{0.05 \text { farming system }=} 6.99 ; \mathrm{LSD}_{0.05}$

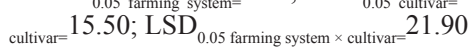


Results of the three-factor analysis of variance show that tyrosine content mostly depends on the individual properties of potato cultivar (coefficient $\eta^{2}$ variety $=0.65$ ) of all investigated factors. Other researchers exploring the free tyrosine content in potato tubers also confirmed its dependence on cultivar (ANDRE et al., 2009; NAVARRE et al., 2011; AYVAZ et al., 2015). The recorded amounts of tyrosine in potato tubers range from $24 \mu \mathrm{g} \mathrm{g}^{-1}$ to 231 $\mu \mathrm{g} \mathrm{g}^{-1}$.

Tryptophan content in potato tubers is determined by the interaction of year, farming type, and cultivar $(\mathrm{P}<0.001)$. Therefore, the results of the years 2011 and 2012 are discussed separately. It was noted that in 2011 , organically grown potato tubers accumulated significantly higher amounts of tryptophan than conventionally grown ones, while in 2012 the opposite was observed $(\mathrm{P}<0.001)($ Table 4$)$.

Table 4. Average amount of free tryptophan accumulated in organically and conventionally grown potato tubers of different cultivars

\begin{tabular}{|c|c|c|c|c|c|c|c|c|c|c|c|c|}
\hline \multirow[b]{2}{*}{ Years } & \multicolumn{12}{|c|}{ Amount of free tryptophan, $\mu \mathrm{g} \mathrm{g}^{-1}$} \\
\hline & $\begin{array}{c}\text { VB } \\
\text { Venta }\end{array}$ & $\begin{array}{l}\text { Aca- } \\
\text { pella }\end{array}$ & Fresco & $\begin{array}{c}\text { VB } \\
\text { Liepa }\end{array}$ & Sante & Goda & $\begin{array}{l}\text { Cour- } \\
\text { age }\end{array}$ & $\begin{array}{c}\text { Red } \\
\text { Lady }\end{array}$ & $\begin{array}{l}\text { Lady } \\
\text { Ro- } \\
\text { setta }\end{array}$ & $\begin{array}{l}\text { Sat- } \\
\text { urna }\end{array}$ & $\begin{array}{c}\text { VB } \\
\text { Rasa }\end{array}$ & $\begin{array}{c}\text { VB } \\
\text { Aista }\end{array}$ \\
\hline \multicolumn{13}{|c|}{ Organically grown } \\
\hline $2011^{*}$ & 58 & 72 & 36 & 42 & 46 & 46 & 32 & 47 & 19 & 38 & 47 & 77 \\
\hline $2012^{* *}$ & 38 & 41 & 34 & 37 & 40 & 37 & 27 & 36 & 14 & 23 & 26 & 49 \\
\hline \multicolumn{13}{|c|}{ Conventionally grown } \\
\hline $2011^{*}$ & 51 & 61 & 46 & 23 & 38 & 24 & 40 & 49 & 17 & 25 & 38 & 49 \\
\hline $2012^{* *}$ & 48 & 60 & 32 & 68 & 37 & 52 & 21 & 70 & 13 & 25 & 47 & 30 \\
\hline
\end{tabular}

In 2011, organically grown tubers accumulated more tryptophan compared with 2012 $(\mathrm{P}<0.05)$, while in conventionally grown potato tubers the amounts of free tryptophan in 2011-2012 did not significantly differ $(\mathrm{P}>0.05)$. It is known that tryptophan synthesis in plants intensifies as plants are forced to fight against various pathogens and pests (RADWANSKI \& LAST, 1995; LovaT et al., 2015).

Results of the three-factor analysis of variance show that tryptophan content mostly depends on the individual properties of potato cultivar (coefficient $\eta^{2}$ variety $=0.50$ ) of all investigated factors. The recorded tryptophan contents in potato tubers range from $13 \mu \mathrm{g} \mathrm{g}^{-1}$ to $77 \mu \mathrm{g} \mathrm{g}^{-1}$. Other authors state that free tryptophan content in potato tubers depends on the cultivar and ranges from $2 \mu \mathrm{g} \mathrm{g}^{-1}$ to $73 \mu \mathrm{g} \mathrm{g}^{-1}$ of fresh potato (ANDRE et al., 2009).

Assessment of the impact of time of maturity on the amounts of tested compounds in tubers of twelve potato cultivars revealed that it has a significant effect on the amounts of chlorogenic acid, tyrosine, and tryptophan derivatives $(\mathrm{P}<0.01)$, however, these are often affected by growth conditions during the particular year and by the applied farming type. 


\section{Conclusions}

It was determined that amounts of chlorogenic acid, tyrosine, and tryptophan in potato tubers depend on meteorological conditions, farming type, individual properties of a cultivar, and on the interaction of these factors $(\mathrm{P}<0.05)$. It was noted that in 2011 organically grown potato tubers accumulated significantly higher amounts of chlorogenic acid, tyrosine, and tryptophan derivatives than conventionally grown tubers, while in 2012 the opposite was observed $(\mathrm{P}<1.001)$. Such results are due to different meteorological conditions during the survey years.

Investigated potato cultivars have different times of maturity (very early: 'VB Venta', 'Fresco', 'Acapella'; early: 'Sante', 'Goda', 'VB Liepa'; medium: 'Lady Rosetta', 'Red Lady', 'Courage'; late: 'VB Rasa', 'VB Aista', 'Saturna') and statistically significant difference $(\mathrm{P}<0.01)$ between the total amount of active compounds accumulated in the potato cultivars with different time of maturity was found: very early potato cultivars accumulate higher levels of active compounds than others; between the accumulated total amounts of active compounds in early, medium early, and late potato cultivars no statistically significant difference was found. Statistically significant difference $(\mathrm{P}<0.01)$ between the total amount of active compounds accumulated in different cultivars was also found.

Research results were obtained through a long-term research program "Genetics and purposeful change of genotypes of agricultural and forest plants" implemented by Lithuanian Research Centre for Agriculture and Forestry.

\section{References}

Andre, C.M., Oufir, M., Hoffmann, I., Hausman, J.F., Rogez, H., Larondelle, Y. \& Evers, D. (2009): Influence of environment and genotype on polyphenol compounds and in vitro antioxidant capacity of native Andean potatoes (Solanum tuberosum L.). J. Food Compos. Anal., 22, 517-524.

Ayvaz, H., Bozdogan, A., Giusti, M.M., Mortas, M., Gomes, R. \& Saona, L.E.R. (2015): Improving the screening of potato breeding lines for specific nutritional traits using portable mid-infrared spectroscopy and multivariate analysis. Food Chem., 211, 374-382.

Buivydaite, V.V. (2005): Soil survey and available soil data in Lithuania. European Soil Bureau - Research Report No. 9, 211-223.

Chun, O.K., Kim, D.O., Smith, N., Schroeder, D., Han, J.T. \& Lee, C.Y. (2005): Daily consumption of phenolics and total antioxidant capacity from fruit and vegetables in the American diet. J. Sci. Food Agr., 85, 1715-1724.

Dangour, A.D., Dodhia, S.K., Hayter, A., Allen, E., Lock, K. \& Uauy, R. (2009): Nutritional quality of organic foods: a systematic review. Am. J. Clin. Nutr., 90, 680-685.

FAO (2011): Statistical Databases http://faostat3.fao.org/home/index.html\#download (last accessed 12 December 2016)

Gilsenan, C., Burke, R.M. \& Barry-Ryan, C. (2010): A study of the physicochemical and sensory properties of organic and conventional potatoes (Solanum tuberosum) before and after baking. Int. J. Food Sci. Tech., 45, 475-481.

Hajslova, J., Schulzova, V., Slanina, P., Janne, K., Hellenas, K.E. \& Andersson, C.H. (2005): Quality of organically and conventionally grown potatoes: Four-year study of micronutrients, metals, secondary metabolites, enzymatic browning and organoleptic properties. Food Addit. Contam., 22, 514-534.

Hoefrens, Ch., Vandekinderen, I., Meulenaer, B., Devlieghere, F., Baert, K., Sioen, I., Henauw, S.D., Verbeke, W. \& CAMP, J.V. (2008): A literature-based comparison of nutrient and contaminant contents between organic and conventional vegetables and potatoes. Brit. Food J., 111, 1078-1097.

Lovat, C., Nassar, A.M.K., Kubow, S., Li, X. \& Donnelly, D.J. (2015): Metabolic biosynthesis of potato (Solanum tuberosum L.) antioxidants and implications for human health. Crit. Rev. Food Sci. Nutr., 56, 2278-2303. 
Meena, B.P., Kumar, A., Dotaniya, M.L., Jat, N.K. \& LaL, B. (2016): Effect of organic sources of nutrients on tuber bulking rate, grades and specific gravity of potato tubers. P Natl. A Sci. India B, 86(1), 47-53.

Navarre, D.A., Pillai, S.S., Shakya, R. \& Holden, M.J. (2011): HPLC profiling of phenolics in diverse potato genotypes. Food Chem., 127, 34-41.

Pineros-Nino, C., Narvaez-Cuenca, C.E., Kushalappa, A.C. \&Mosquera, T. (2016): Hydroxycinnamic acids in cooked potato tubers from Solanum tuberosum group Phureja. Food Sci. Nutr., 4(5), DOI: 10.1002/fsn3.403

RADWANSKI, E.R. \& LAST, R.L. (1995): Tryptophan biosynthesis and metabolism: biochemical and molecular genetics. Plant Cell, 7, 921

Tömösközi-Farkas, R., Berki, M., Nagy-Gasztonyi, M., Wolf, I. \& Polgár, Zs. (2014a): Investigation of antinutritive components in Hungarian potato cultivars depending on production technology. Acta Alimentaria, 43, 188-196.

TömösköZi-Farkas, R., Polgár, Zs., Nagy-Gasztonyi, M., Horváth, V., Renkecz, T., Simon, K., Boross, F., Fabulya, Z. \& DAOOD, H. (2014b): Changes of potentially anti-nutritive components in Hungarian potatoes from organic and conventional farming. Acta Alimentaria, 43, 676-683. 